\title{
Early experience with remdesivir in SARS-CoV-2 pneumonia
}

\author{
Emanuele Durante-Mangoni ${ }^{1,2}$ (D) $\cdot$ Roberto Andini $^{2} \cdot$ Lorenzo Bertolino $^{1} \cdot$ Ferruccio Mele $^{1} \cdot$ Letizia Lucia Florio $^{1}$. \\ Patrizia Murino ${ }^{3} \cdot$ Antonio Corcione $^{3} \cdot$ Rosa Zampino $0^{1,2}$
}

Received: 4 April 2020 / Accepted: 12 May 2020 / Published online: 16 May 2020

(c) Springer-Verlag GmbH Germany, part of Springer Nature 2020

\begin{abstract}
At present, there is no definitive antiviral treatment for coronavirus disease 2019 (COVID-19). We describe our early experience with remdesivir in four critically ill COVID-19 patients. Patients received a $200 \mathrm{mg}$ loading dose, followed by $100 \mathrm{mg}$ daily intravenously for up to 10 days. All patients had been previously treated with other antivirals before remdesivir initiation. One patient experienced a torsade de pointes requiring cardiac resuscitation and one died due to multiple organ failure. Three patients showed biochemical signs of liver injury. Lymphocyte count increased in all patients soon after remdesivir initiation. Nasal swab SARS-CoV-2 RNA became negative in three of four patients after 3 days of therapy. We observed an in vivo virological effect of remdesivir in four critically ill, COVID-19 patients, coupled with a significant burden of adverse events. Although limited by the low number of subjects studied, our preliminary experience may be relevant for clinicians treating COVID-19.
\end{abstract}

Keywords Remdesivir $\cdot$ SARS-CoV-2 $\cdot$ COVID $19 \cdot$ Pneumonia $\cdot$ Antiviral therapy

The severe acute respiratory syndrome coronavirus 2 (SARS-CoV-2) emerged in China in December 2019, causing severe pneumonia and acute respiratory distress syndrome [1]. Over the following few months, infection spread worldwide and WHO declared the status of a pandemic in March 11, 2020.

Currently, no definitive antiviral treatment for coronavirus disease 2019 (COVID-19) has been identified. Lopinavir/ritonavir (LPV/r) combination was not effective in adult patients with severe COVID-19 [2]. Hydroxychloroquine (HCQ) exhibits a consistent inhibitory activity on SARSCoV-2 in vitro [3] and has shown promising results in a small cohort of patients with different severity of disease [4]. Remdesivir (RDV), a newer nucleotide analogue RNA polymerase inhibitor, originally developed for Ebola virus

Emanuele Durante-Mangoni

emanuele.durante@unicampania.it

1 Division of Internal Medicine, University of Campania 'L. Vanvitelli', Monaldi Hospital, Piazzale Ettore Ruggieri, 80131 Naples, Italy

2 Unit of Infectious and Transplant Medicine, AORN Ospedali dei Colli-Monaldi Hospital, Naples, Italy

3 Intensive Care Unit, AORN Ospedali dei Colli-Monaldi Hospital, Naples, Italy disease, shows in vitro efficacy against coronaviruses, including SARS-CoV-2 [5]. Recent clinical data on the efficacy and safety of RDV for COVID-19 have been published [6]. Thus, while clinical trials are ongoing, additional experience can be derived from initial COVID-19 cases treated with RDV.

We describe our early clinical experience with the use of RDV in four COVID-19 patients admitted to the Monaldi Hospital, Naples, Italy, in March 2020, because of severe pneumonia and respiratory distress. Treatment was given in the context of a compassionate use program approved by EMA and our Institution Ethics Committee. All patients had been previously treated with LPV/r or darunavir/cobicistat (DRV/c) and also received hydroxychloroquine, as per current Italian clinical recommendations.

Figure 1 summarizes the major clinical, biochemical and virological data of these four patients during their hospitalization. Antivirals administered and the results of SARS-CoV-2 RNA testing on nasal swabs are also shown. APACHE II score, pneumonia severity index and multiple organ dysfunction scores changed during treatment according to the individual patient response, as depicted in Fig. 1.

Patients received HCQ (200 mg twice daily po) and LPV/r (400/100 mg twice daily po) for a variable number of days as indicated in Fig. 1. Two patients had to switch 


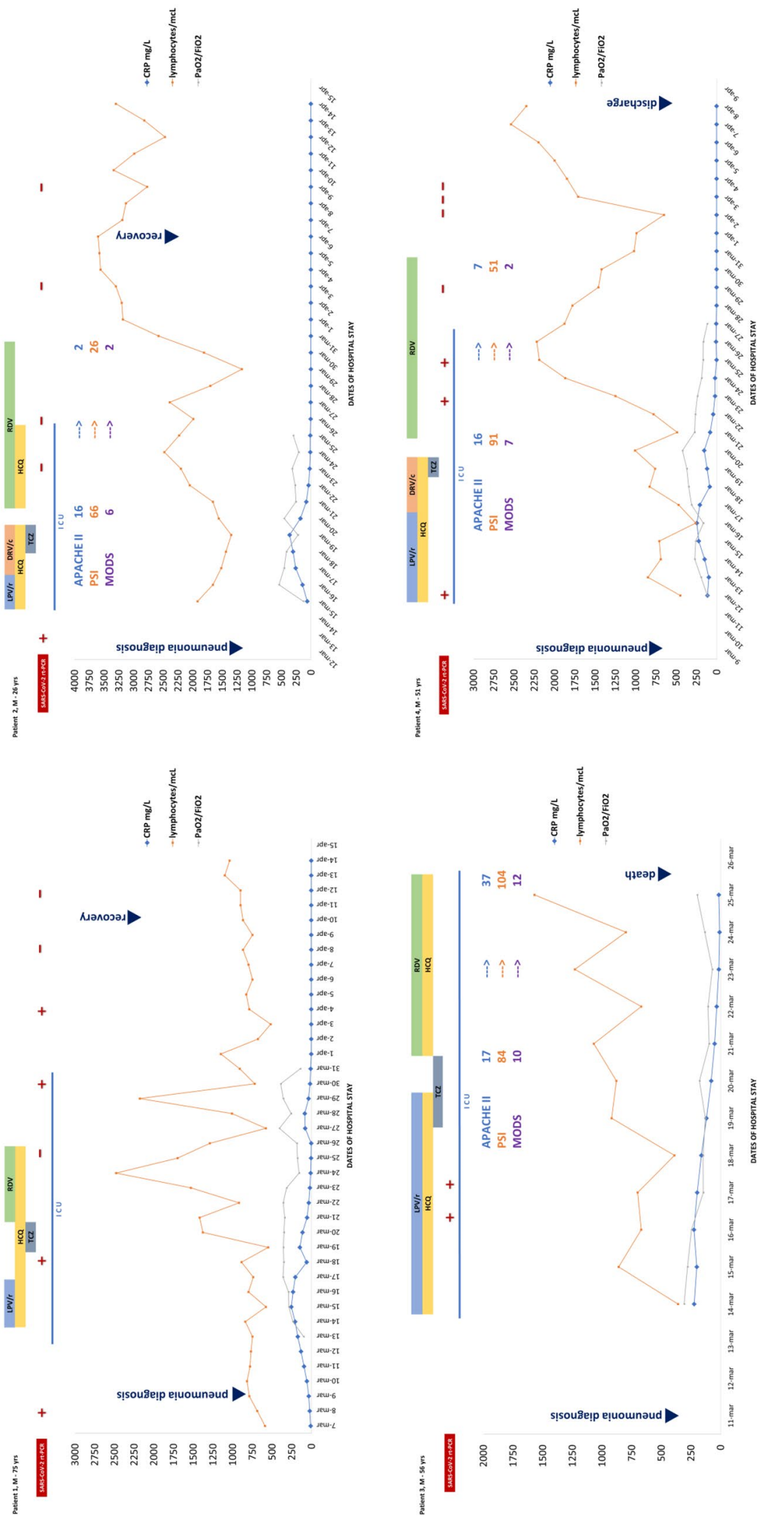

官 $\dot{0}=$

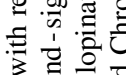

可

ฮึ.

䒕言高票

视的

引

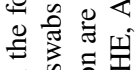

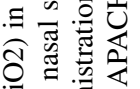

过奉六

ญี.

宕跑志

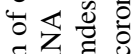

음 든

方至

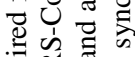

触苋总

늉

สิษ

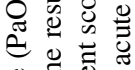

忥 苋

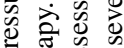

ป छ

क्ष

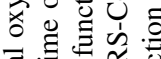

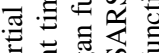

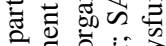

ฮี

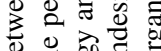

Ð

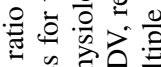

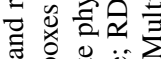

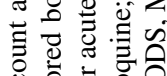

ช 흫ㅎㅇ응

융혀

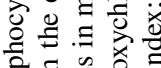

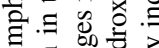

太ี

बิ

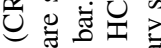

미웛

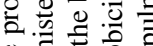

릴ㅎㅇ

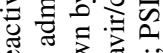

Uัँ

施。

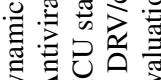

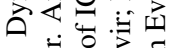

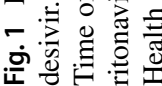


from LPV/r to DRV/c (800/150 mg once daily po) due to shortage of the former drug. Of note, before RDV was initiated, all other antivirals were stopped. However, HCQ was restarted in combination with RDV in three patients. RDV was given as a $200 \mathrm{mg}$ loading dose on day 1 , followed by $100 \mathrm{mg}$ daily as intravenous infusion over $1 \mathrm{~h}$.

RDV was prematurely discontinued in patient 1 because of a torsade de pointes requiring cardiac resuscitation and in patient 3 because of death due to multiple organ failure. In patient 1 , QT prolongation was observed after arrhythmia resolution. This patient survived and is currently improving outside of the intensive care unit. Patients 1, 2 and 3 also experienced both ALT and AST increase, ranging from 5 to 8 times the upper normal limit.

Lymphocyte count increased in all patients after RDV treatment start. However, the four patients also received tocilizumab, $800 \mathrm{mg}$ intravenous infusion in the days immediately preceding RDV start (Fig. 1).

Nasal swab SARS-CoV-2 RNA became negative in three of four RDV-treated patients (Fig. 1). However, in patient 1 SARS-CoV-2 RNA test reverted to positive after RDV discontinuation. Thus, a shorter course of RDV correlated to a transient viral suppression, whereas a longer course translated into a seemingly more stable viral clearance. Patient 3 did not repeat nasal swab before dying.

Our study is limited by the low number of subjects included and the heterogeneity of treatments received before and during RDV administration. Notwithstanding, in the absence of large trials, our early experience may be relevant for other clinicians caring for COVID-19 patients.

In conclusion, we provide preliminary evidence for a clinically relevant, in vivo virological effect of RDV against SARS-CoV-2. Nasal viral load had remained persistently positive in these critically ill patients despite treatment with either LPV/r or DRV/c combined with HCQ. Although previously treated also with tocilizumab, three of our four critically ill COVID-19 patients experienced a clear clinical improvement on RDV treatment. However, initiation of this drug in combination with HCQ also translated into a significant burden of adverse events, requiring close monitoring. Larger studies are clearly warranted and strongly awaited to confirm RDV safety and effectiveness for COVID-19.

\section{Availability of data and material (data transparency)}

All data are available from hospital files, electronic medical records as well as the Medidata electronic data capturing system for remdesivir compassionate use.

Author contributions EDM, RA, and LB worked on the concept of the study; RA, LB, FM, LLF, and RDR worked on data collection and data interpretation; EDM, AC, and RZ drafted the manuscript; all authors critically revised the manuscript and approved the final draft.

Funding No specific funding was obtained for this study. Remdesivir was provided by Gilead Sciences in a compassionate use program approved by EMA and our Institution Ethics Committee.

\section{Compliance with ethical standards}

Conflicts of interest None of the authors has any conflict of interest relevant to the content of this work. There are no competing interests.

Ethics approval Remdesivir use and data collection were approved by the Ethics Committee of the University of Campania and AORN Ospedali dei Colli (delibera AOC/8468/2020 of 18/03/2020).

Consent to participate No consent was obtained from patients who were in an unconscious state.

Consent for publication No consent was obtained from patients who were in an unconscious state.

\section{References}

1. Zhu N, Zhang D, Wang W, Li X, Yang B, Song J, Zhao X, Huang B, Shi W, Lu R, Niu P, Zhan F, Ma X, Wang D, Xu W, Wu G, Gao GF, Tan W. A Novel Coronavirus from Patients with Pneumonia in China, 2019. N Engl J Med. 2020;382:727-33. https://doi.org/10.1056/NEJMoa2001017.

2. Cao B, Wang Y, Wen D, Liu W, Wang J, Fan G, Ruan L, Song B, Cai Y, Wei M, Li X, Xia J, Chen N, Xiang J, Yu T, Bai T, Xie X, Zhang L, Li C, Yuan Y, Chen H, Li H, Huang H, Tu S, Gong F, Liu Y, Wei Y, Dong C, Zhou F, Gu X, Xu J, Liu Z, Zhang Y, Li H, Shang L, Wang K, Li K, Zhou X, Dong X, Qu Z, Lu S, Hu X, Ruan S, Luo S, Wu J, Peng L, Cheng F, Pan L, Zou J, Jia C, Wang J, Liu X, Wang S, Wu X, Ge Q, He J, Zhan H, Qiu F, Guo L, Huang C, Jaki T, Hayden FG, Horby PW, Zhang D, Wang C. A trial of lopinavir-ritonavir in adults hospitalized with severe Covid-19. N Engl J Med. 2020. https://doi.org/10.1056/NEJMo a2001282.

3. Zhou D, Dai SM, Tong Q. COVID-19: a recommendation to examine the effect of hydroxychloroquine in preventing infection and progression. J Antimicrob Chemother. 2020. https:// doi.org/10.1093/jac/dkaa114.

4. Gautret P, Lagier JC, Parola P, Hoang VT, Meddeb L, Mailhe M, Doudier B, Courjon J, Giordanengo V, Vieira VE, Dupont HT, Honoré S, Colson P, Chabrière E, La Scola B, Rolain JM, Brouqui P, Raoult D. Hydroxychloroquine and azithromycin as a treatment of COVID-19: results of an open-label non-randomized clinical trial. Int J Antimicrob Agents. 2020;20:105949. https://doi.org/10.1016/j.ijantimicag.2020.105949.

5. Wang M, Cao R, Zhang L, Yang X, Liu J, Xu M, Shi Z, Hu Z, Zhong W, Xiao G. Remdesivir and chloroquine effectively inhibit the recently emerged novel coronavirus (2019-nCoV) in vitro. Cell Res. 2020;30:269-71.

6. Grein J, Ohmagari N, Shin D, Diaz G, Asperges E, Castagna A, Feldt T, Green G, Green ML, Lescure FX, Nicastri E, Oda R, Yo K, Quiros-Roldan E, Studemeister A, Redinski J, Ahmed S, Bernett J, Chelliah D, Chen D, Chihara S, Cohen SH, Cunningham J, D’Arminio Monforte A, Ismail S, Kato H, Lapadula G, L'Her 
E, Maeno T, Majumder S, Massari M, Mora-Rillo M, Mutoh Y, Nguyen D, Verweij E, Zoufaly A, Osinusi AO, DeZure A, Zhao Y, Zhong L, Chokkalingam A, Elboudwarej E, Telep L, Timbs L, Henne I, Sellers S, Cao H, Tan SK, Winterbourne L, Desai P,
Mera R, Gaggar A, Myers RP, Brainard DM, Childs R, Flanigan T. Compassionate Use of Remdesivir for Patients with Severe Covid-19. N Engl J Med. 2020. https://doi.org/10.1056/NEJMo a2007016. 